\title{
Selection of Chloroplasts by Laser Microbeam Microdissection for Single-Chloroplast PCR
}

H. Meimberg ${ }^{1}$, S. Thalhammer $^{1}$, A. Brachmann ${ }^{2}$, B. Müller ${ }^{1}$, L.A. Eichacker ${ }^{1}$, W.M. Heckl ${ }^{1}$, and G. Heubl ${ }^{1}$ ${ }^{1}$ Ludwig-Maximilians-Universität, München, Germany and ${ }^{2}$ National Institutes of Health, Bethesda, MD, USA

\section{INTRODUCTION}

Laser-based systems are the stateof-the-art technologies for precise and noncontact micromanipulations with nanometer accuracy $(1,2)$. The forces of light are utilized to catch and move, cut, or fuse microscopically small specimens. To accomplish this, lasers of high beam quality are interfaced into a research microscope and focused through the objective onto the sample. Most biological objects are transparent for the applied laser wavelength, and the effective light force acts only within the nanometer-sized laser focal spot (3). Thus, it is possible to handle biological materials without changing features or even to work inside living cells without disturbing their viability.

These systems became indispensable tools in modern medicine and biotechnology. Recent advances in molecular methods to analyze genes and their transcripts necessitated the development of technologies to extract homogeneous specimens of morphologically defined origin for the subsequent genetic or proteomic analysis without contamination. This was achieved by the capture of microdissected specimens using the technology of laser capture microdissection (LCM) (4). A recent improvement of this method is the combination of laser microbeam microdissection (LMM) with laser pressure catapulting (LPC) $(5,6)$.

With the use of LMM, biological material can be isolated from neighboring tissue. The laser cuts around the target specimen, which yields a clear-cut gap between the selected and nonselected specimens. In addition, unwant- ed material within a larger selected area can be selectively destroyed with a few laser shots. After this step, using LPC, the isolated material is ejected from the object plane with a single laser shot and catapulted directly into the cap of a standard reaction vessel. The basis of this technique is believed to be the laser pressure force that develops under the specimen and is caused by the extremely high photon density of the precisely focused laser microbeam (5). The isolated sample is driven with high speed along the wave front of the photonic stream and can be transported for several millimeters, even against gravity (6). After catapulting and capturing, the probes are suspended in appropriate buffers in the cap of the reaction vessel and subsequently centrifuged down into the tube for further processing.

The 337-nm nitrogen laser works within the UV-A range; nevertheless, damage of biological matter could occur. However, within the laser-catapulted specimen and the adjacent tissue, the recovery of DNA, RNA, or protein is not impaired (5), which makes this technique ideal for sample preparation before single-cell PCR (7).

Specimens of any shape and size from one to several micrometers in diameter can be captured in a quick and reliable manner. Catapulting can be performed on large areas of tissue or single cells from frozen or fixed histological tissue slices as well as from cytocentrifuged samples or cell smear. Even fragile structures such as chromosomes can be collected using the same principle (8).

The amplification of microdissected chromosomes or nuclei is already a 
standard technique for the generation of specific DNA probes used in chromosome mapping and chromosome walking (9-11), for fluorescence in situ hybridization (12), or for the generation of genomic libraries of single or partial chromosomes via microcloning procedures $(13,14)$. In these applications, several samples are pooled to increase the amount of DNA for subsequent use.

Applications of single-cell PCR are used when the material is limited, such as in prenatal diagnostics, where single embryonic cells are isolated, or when somatic cells are differentiated after mutation, as in cancer research (7). LMM and LPC are powerful tools for the isolation of single cells and organelles for subsequent molecular analysis and amplification of DNA via PCR $(5,15,16)$. This technique is easier to use and results in a higher efficiency than systems that depend on microcapillary needles (7).

Although micromanipulation via laser microbeam and optical tweezers has been widely used on living plant cells (for an overview, see Reference 17 ) and on chloroplasts (18), the isolation of plant material via LPC for use in single-cell PCR has thus far only been reported for single pollen typing (19). In the context of experiments that test for heteroplasmy in populations of chloroplasts, we were interested in the examination of high numbers of single chloroplasts. Here we describe the highthroughput and contamination-free isolation of single chloroplasts and their successful use in single-organelle PCR.

\section{MATERIALS AND METHODS}

\section{Plant Material}

In vitro cultured material from $\mathrm{Nico}-$ tiana tabacum was used for all of the experiments shown. Additional experiments were performed with material from Taraxacum officinale.

\section{Isolation of Chloroplasts}

For the isolation of chloroplasts, a previously described buffer system (20) was used, and the following modifications were introduced to enable the micropreparation of plastids from low amounts of leaf material. Fresh leaf material (1-2 $\left.\mathrm{cm}^{2}\right)$ was cut into small pieces with a sharp razor blade on an ice-cold glass plate. The material was homogenized with a micropestle on ice in a $1.5-\mathrm{mL}$ reaction vessel with $1 \mathrm{~mL}$ homogenization buffer $(50 \mathrm{mM}$

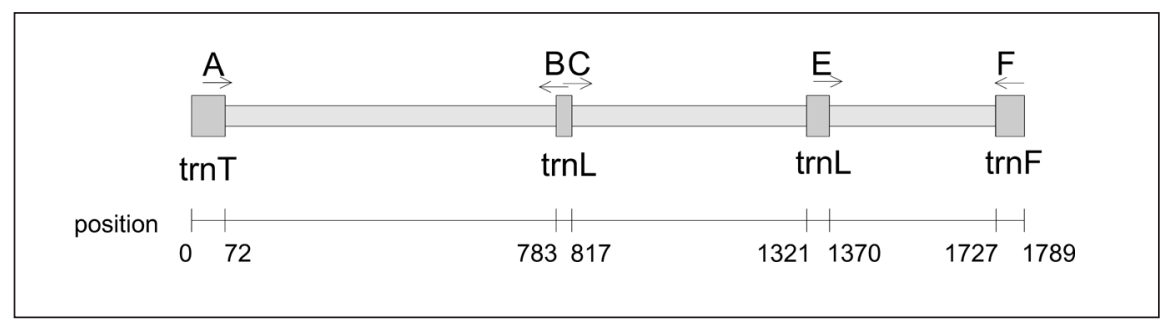

Figure 1. The trnT-trnF region of $N$. tabacum. The dark gray boxes indicate conserved regions and the light gray boxes indicate variable regions. Oligonucleotide positions A, B, C, E, and F are as previously indicated (22) and also apply to the nested primers A2 E2, F2, and F3 designed for this study.

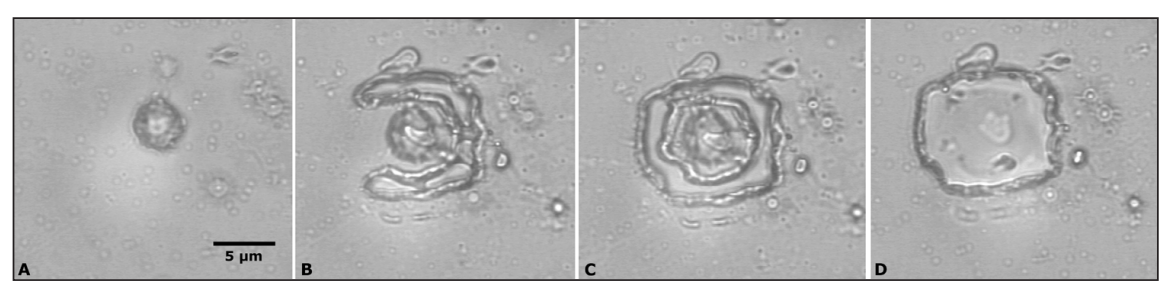

Figure 2. Separation of one single chloroplast. (A) A single chloroplast from a chloroplast solution fixed on a microscope slide-mounted PEN membrane before the microdissection process; (B) LMM of the supporting PEN membrane around the single chloroplast; (C) microdissected PEN membrane islet with the single chloroplast; and (D) region of the supporting membrane after LPC of the selected specimen into a PCR tube cap. The size bar in panel A applies to all pictures.
HEPES/KOH, pH 8.0, $400 \mathrm{mM}$ sorbitol) and a small amount of inert sea sand (Merck, Munich, Germany). The suspension was cleared by centrifugation through a layer of nylon gaze $(\varnothing 22$ $\mu \mathrm{m})$ at $3000 \times \mathrm{g}$ for $1 \mathrm{~min}$ at $4^{\circ} \mathrm{C}$. The pellet was resuspended in 100-200 $\mu \mathrm{L}$ homogenization buffer and layered onto an ice-cold Percoll ${ }^{\mathrm{TM}}$ gradient in a 1.5 $\mathrm{mL}$ reaction vessel $(600 \mu \mathrm{L} 40 \%$ Percoll on top of $600 \mu \mathrm{L} 80 \%$ Percoll, both in homogenization buffer). After centrifugation in a swing-out rotor (HB4, Sorvall ${ }^{\circledR}$; Kendro Laboratory Products, Newtown, CT, USA) at $4500 \times g$ for 10 min at $4{ }^{\circ} \mathrm{C}$, the chloroplast layer above the $80 \%$ Percoll layer was transferred to a new reaction vessel containing $1 \mathrm{~mL}$ homogenization buffer and pelleted by centrifugation at $3000 \times g$ for $1 \mathrm{~min}$ at $4^{\circ} \mathrm{C}$. This was repeated twice to remove all of the remaining Percoll. The pellet was resuspended in $10 \mu \mathrm{L}$ homogenization buffer and applied directly onto a poly-ethylene-naphthalate (PEN) membrane (P.A.L.M. Microlaser Technologies $\mathrm{AG}$, Bernried, Germany) fixed at its edge with nail varnish on a microscope slide. In subsequent experiments, the chloroplast suspension was further diluted with the homogenization buffer before application to the membrane (see Results and Discussion). The sample was carefully dispersed on the membrane with a pipet tip until it formed a thin layer and dried for several minutes at $37^{\circ} \mathrm{C}$ (see Figure $2 \mathrm{~A}$ ).

\section{LMM}

A commercially available UV-laser microbeam system (ROBOT-Microbeam; P.A.L.M. Microlaser Technologies $A G)$ was used as previously described in detail (21). This system consists of a 337-nm nitrogen laser that is coupled with the light path of an inverted microscope and focused through an oil immersion objective $(100 \times$ magnification) with a high numerical aperture to yield a spot size of less than 1 $\mu \mathrm{m}$ in diameter (2). The positioning of the stage in the $\mathrm{x}$ - and $\mathrm{y}$-directions is computer-controlled. The microscopic image is taken by a video camera, displayed on a video screen, and stored by the computer. The position of the laser beam during the isolation procedure can be controlled online on the video 


\section{Research Report}

screen. An energy of $0.2-0.3 \mu \mathrm{J}$ per pulse was used for ablation, and an energy of $0.5-0.6 \mu \mathrm{J}$ per pulse was used for membrane dissection. The area around one chloroplast visible on the video screen was cut with the laser beam until it was completely separated from the neighboring membrane. Chloroplast-free islets were isolated in the same manner and used as a control.

\section{LPC}

For catapulting, the laser was focused slightly below the membrane. The isolated sample-membrane islets were ejected and hovered on a photonic cloud from the object slide with a single laser shot of 1-2 $\mu \mathrm{J}$ per pulse, as shown (see Figure 2). The collecting device consists of the flat cap of a $0.2-\mathrm{mL}$ reaction vessel mounted onto the LPC collector. The LPC collector was positioned at a distance of about $1 \mathrm{~mm}$ above the slide with the help of the computer-controlled Robot-Manipulator. The microfuge caps were covered with $1 \mu \mathrm{L}$ mineral oil to improve the adhesion of the captured specimen and to facilitate their release into the reaction tube.

\section{Proteinase K Incubation}

The cap was removed immediately from the LPC collector, and $25 \mu \mathrm{L} 1 \times$ PCR buffer (10 mM Tris-Cl, pH 8.3, 50 $\mathrm{mM} \mathrm{KCl}, 1.5 \mathrm{mM} \mathrm{MgCl}$ ) with 0.23 $\mu \mathrm{g} / \mu \mathrm{L}$ proteinase $\mathrm{K}$ (PCR-grade; Roche Applied Science) were added to the middle of the cap. The cap was covered with the corresponding reaction vessel and incubated until all of the samples had been dissected. After centrifugation at $14,000 \times g$ for $10 \mathrm{~min}$ at room temperature, the samples were incubated for $60 \mathrm{~min}$ at $65^{\circ} \mathrm{C}$ and subsequently for $10 \mathrm{~min}$ at $94^{\circ} \mathrm{C}$ to inactivate the proteinase $\mathrm{K}$.

\section{PCR Amplification}

The DNA amplified was the plastome region between the trnT and trnF genes, consisting of the two conserved coding regions of $\operatorname{trn} L$, the variable $\operatorname{trn} L$ intron, and two variable intergenic regions. Primers were placed in the conserved regions (Figure 1). Because of the high sequence variability, we were able to eliminate the possibility of contaminations from other plant species during the first experiments. Each of the amplifications was performed with the same number of samples, containing chloroplasts and chloroplast-free samples as control, generally 20 samples of each. In addition, a negative PCR control was performed. Modified oligonucleotides A2 (5'-CATTACAAATGCGATGC-3') and F2 (5'-ATTTGAACTGGTGACAC-3') were used as described previously (22) to amplify the entire region in the first PCR. The reaction mixture, consisting of $25 \mathrm{pmol}$ each primer, $2.5 \mu \mathrm{L}$ dNTPs $(2.5 \mathrm{mM}$ each nucleotide), $2.5 \mu \mathrm{L} 10 \times \mathrm{PCR}$ buffer, and 2 U Taq DNA polymerase (Roche Applied Science, Mannheim, Germany) in a total volume of $25 \mu \mathrm{L}$, was added directly to the sample. All PCRs were run on a Primus 96 thermal cycler (MWG, Ebersberg, Germany). After 2 min of denaturation at $94^{\circ} \mathrm{C}$, the following "touch-down" profile was used: two cycles of $55^{\circ} \mathrm{C}$ for $1 \mathrm{~min}, 72^{\circ} \mathrm{C}$ for 2.5 $\mathrm{min}$, and $94^{\circ} \mathrm{C}$ for $1 \mathrm{~min}$; two cycles of $50^{\circ} \mathrm{C}$ for $1 \mathrm{~min}, 72^{\circ} \mathrm{C}$ for $2.5 \mathrm{~min}$, and $94^{\circ} \mathrm{C}$ for $1 \mathrm{~min}$; 10 cycles of $48^{\circ} \mathrm{C}$ for 1 min, $72^{\circ} \mathrm{C}$ for $2.5 \mathrm{~min}$, and $94^{\circ} \mathrm{C}$ for 1 min; 20 cycles of $48^{\circ} \mathrm{C}$ for $1 \mathrm{~min}, 72^{\circ} \mathrm{C}$ for $2.5 \mathrm{~min}$, with an elongation step of 2 $\mathrm{s}$ for each cycle, and $94^{\circ} \mathrm{C}$ for $1 \mathrm{~min}$. Finally, elongation at $72^{\circ} \mathrm{C}$ for $10 \mathrm{~min}$ was performed. The reaction products were used as template in a second amplifica- tion using either oligonucleotides A $\left(5^{\prime}\right.$ CATTACAAATGCGATGCTCT-3') and B (5'-TCTACCGATTTCGCCATATC-3') (21) or C (5'-CGAAATCGGTAGACGCTACG-3') (21) and F3 (5'CAGTCCTCTGCTCTACCAAC-3'). The expected product sizes were approximately 800 and $1,000 \mathrm{bp}$, respectively. The reactions were performed in a total volume of $25 \mu \mathrm{L}$ with $12.5 \mathrm{pmol}$ each primer, $1.25 \mu \mathrm{L}$ dNTPs $(2.5 \mathrm{mM}$ each nucleotide), $2.5 \mu \mathrm{L} 10 \times$ PCR buffer, $1 \mathrm{U}$ Taq DNA polymerase, and 1 $\mu \mathrm{L}$ reaction product from the first PCR. We used the following temperature profiles. For amplification with $\mathrm{A}$ and $\mathrm{B}$, the initial denaturation was at $94^{\circ} \mathrm{C}$ for 2 min; 35 cycles of $59^{\circ} \mathrm{C}$ for $30 \mathrm{~s}, 72^{\circ} \mathrm{C}$ for $1.5 \mathrm{~min}$, and $94^{\circ} \mathrm{C}$ for $30 \mathrm{~s}$; and final elongation at $72^{\circ} \mathrm{C}$ for $5 \mathrm{~min}$. For amplification with $\mathrm{C}$ and $\mathrm{F} 3$, initial denaturation was at $94^{\circ} \mathrm{C}$ for $2 \mathrm{~min} ; 35$ cycles of $53.2^{\circ} \mathrm{C}$ for $30 \mathrm{~s}, 72^{\circ} \mathrm{C}$ for $1.5 \mathrm{~min}$, and $94^{\circ} \mathrm{C}$ for $30 \mathrm{~s}$; and final elongation at $72^{\circ} \mathrm{C}$ for $5 \mathrm{~min}$. Additional experiments were performed using the primers E2 (5'-GGTTCAAGTCCCTCTAT-3') and F2 in the first PCR, with the following temperature profile: initial denaturation at $94^{\circ} \mathrm{C}$ for $2 \mathrm{~min} ; 2$ cycles of $60^{\circ} \mathrm{C}$ for 1 $\min , 72^{\circ} \mathrm{C}$ for $1 \mathrm{~min}$, and $94^{\circ} \mathrm{C}$ for 1 min; 2 cycles of $55^{\circ} \mathrm{C}$ for $1 \mathrm{~min}, 72^{\circ} \mathrm{C}$ for $1 \mathrm{~min}$, and $94^{\circ} \mathrm{C}$ for $1 \mathrm{~min} ; 2$ cycles of $50^{\circ} \mathrm{C}$ for $1 \mathrm{~min}, 72^{\circ} \mathrm{C}$ for $1.25 \mathrm{~min}$, and $94^{\circ} \mathrm{C}$ for $1 \mathrm{~min}$; and final elongation at $72^{\circ} \mathrm{C}$ for $5 \mathrm{~min}$.

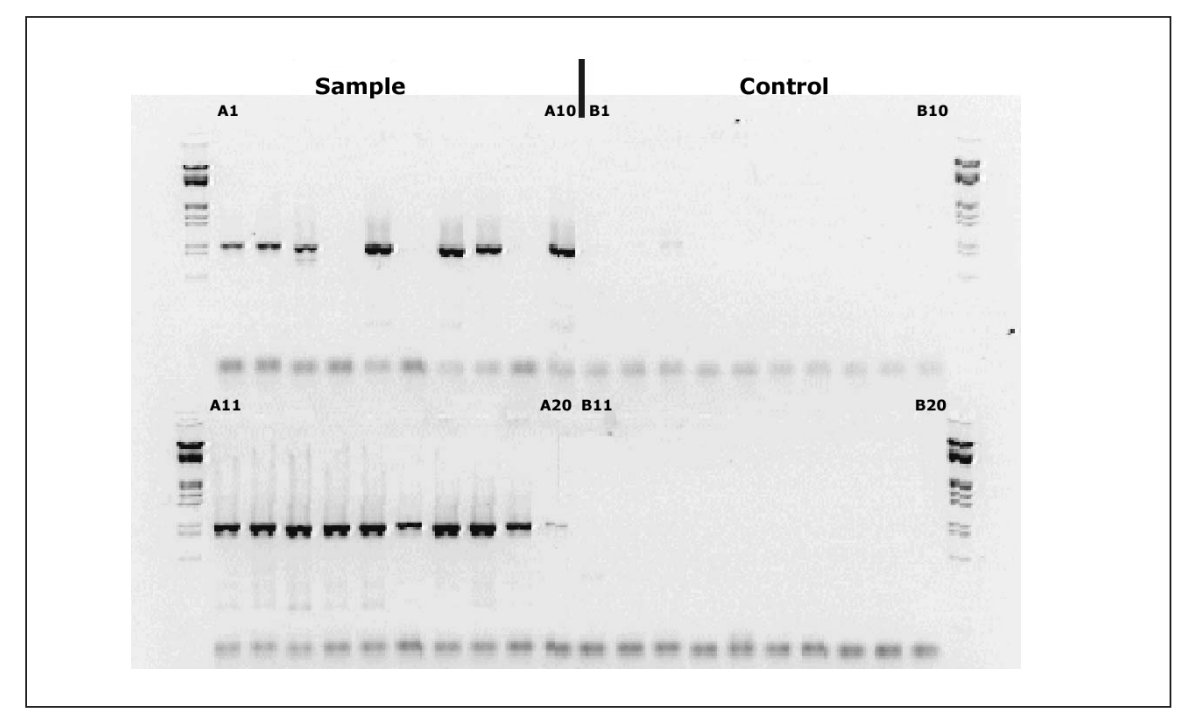

Figure 3. Amplification products after secondary PCR. Twenty samples each from the regions containing chloroplasts (lanes A1 to A20, samples) and from chloroplast-free regions (lanes B1 to B20, controls) were used. PCR was performed using oligonucleotides C and F3. $\lambda$-phage DNA cut with EcoRI and HindIII serves as size standard. 
Reaction products were separated on $1.5 \%$ standard agarose gels. Gel and running buffer were $1 \times$ TBE $(90 \mathrm{mM}$ Tris-borate, $\mathrm{pH}$ 8.3, $2.5 \mathrm{mM}$ EDTA) containing $5 \mu \mathrm{g} / \mathrm{mL}$ ethidium bromide. To verify the specificity of the PCR, samples of positive PCR of one experiment were pooled and sequenced using the same oligonucleotides as for the PCR. Sequencing was performed with biotin terminator-labeled ddNTPs in cycle sequencing reactions with Thermo Sequenase ${ }^{\mathrm{TM}}$ (Amersham Biosciences Europe GmbH, Freiburg, Germany) using a GATC-direct blotter (GATC, Konstanz, Germany).

\section{RESULTS AND DISCUSSION}

\section{Chloroplast Isolation}

The aim of this study was to establish a method for the rapid isolation of single chloroplasts for single-organelle PCR analysis, sufficient for the preparation of numerous samples, which would allow one to work on a level of statistical significance. In the context of a phylogenetic study, we had co-amplified two paralogous sequences from the trnK intron of various Nepenthes species. Because this locus is normally chloroplast encoded, both copies could be located in chloroplasts. Alternatively, one copy could be of nuclear origin or mitochondrially encoded. It was important to distinguish between these possibilities and to determine which copy is chloroplast encoded. To establish the methodology, we chose to use the leaf material of N. tabacum.

After isolation, chloroplasts could be applied directly onto a dry PEN membrane, with no need to prebind adhesive buffers. Plastids kept their spherical shape and could be dissected easily (Figure 2). Good amplification results were achieved only with fresh preparations, indicating that DNase activities persist even in dried material. The addition of EDTA to the isolation medium for the inhibition of DNases was not possible since the hygroscopic nature of EDTA prevents the complete drying of the membrane and disturbs the dissection procedure. The same effect was caused by excess amounts of sorbitol from the homogenization buffer when the samples were not distributed evenly over the membrane.

\section{PCR Amplification}

Amplification with one isolated chloroplast as template with oligonucleotides A2 and F2 in the first PCR never resulted in visible amounts of the expected 1,800 bp product. Since amplification with oligonucleotides E2 and F2 with an expected product size of about 300 bp gave the same result, we 


\section{Research Report}

concluded that a second round of PCR was necessary.

The second round of PCR led to products in $90 \%$ of the samples, with sizes of about 800 and $1000 \mathrm{bp}$ for the oligonucleotides $\mathrm{A}$ and $\mathrm{B}$, and $\mathrm{C}$ and F3, respectively. Sequencing of these products was performed to confirm the specificity of the PCR. A comparison with the $N$. tabacum chloroplast genome DNA sequence (accession no. gi2924257) revealed $100 \%$ identity.

To determine whether DNA of the isolated visible chloroplasts or DNA dispersed in the preparation served as template in the PCR amplifications, chloroplast-free membrane regions were dissected as controls. Amplifications with these control samples resulted in PCR products in $60 \%$ of the cases. This contamination demonstrated that either plastid DNA of ruptured chloroplasts is not quantitatively removed by separation via the Percoll gradient or that chloroplasts not visible under the microscope are present in membrane regions used as control. To circumvent this problem, we diluted the pelleted chloroplasts in homogenization buffer before fixation onto the PEN membrane.

Dilution of the pellet from 1- to 10fold resulted in PCR products in only $30 \%$ of the control reactions, while all of the chloroplast-containing samples gave a positive result. After a further 2fold dilution, $85 \%$ of the reactions with samples that contained visible chloroplasts still led to products, while all controls remained negative (Figure 3 ). With this, we could confirm specific amplification from a single, morphologically intact chloroplast. Additional experiments with $T$. officinale led to analogous results (data not shown).

\section{Application of the Technique}

The advantage of LPC compared to other techniques, such as limited dilution or needle-based micromanipulation, for preparation of single chloroplasts lies in the speed and effectiveness of the procedure. It is possible to verify directly the isolation of a single chloroplast and reduce co-isolated contaminations. To our knowledge, the data presented here are the first reported amplification of DNA using the plastomes of one organelle as template. It is also feasible that thin-layer preparations of leaf sections may be sufficient for the LPC of single chloroplasts, which is a subject currently under investigation. Our data indicate that the quality of the DNA should be sufficient for the amplification of longer fragments. With this isolation procedure, whole plastome analysis using primer-extension-pre-amplification strategies (23) from one chloroplast could also be successful. This has been demonstrated by Matsunaga et al. (19) in the case of single 
LPC-isolated pollen grains, in which the target sequences are present in three copies only. Due to the high copy number of plastomes in a single chloroplast, amplification should be easily achieved.

Therefore, it might also be possible to sample single mitochondria via LPC. Kuroiwa et al. (24) isolated mitochondria using optical tweezers from a suspension and performed PCR from DNA of at least nine mitochondria dried on a glass slide. LPC allows for the collection of single organelles directly in the reaction vessel. Thus, the separation and sampling of single organelles is very efficient with this method. The advantages of LPC as shown for separating single pollen grains (19) will also apply to fragile cell compartiments.

The procedure we present here allows for the direct comparison of plastomes from single organelles to detect the phenomenon of heteroplasmy, such as those described for chloroplasts of Senecio vulgaris (25) or for plastid transformants. The same applies for mitochondria that seem to coexist rather than to segregate in species with biparental inheritance, after fusion experiments and due to mutations of the chondrom (26).

Apart from its use to differentiate organelle populations, we assume this method will be of great benefit for the direct verification of successful transformation of chloroplasts and mitochondria, such as for addressing questions of mitochondrial exclusion or inheritance.

\section{ACKNOWLEDGMENTS}

The authors would like to thank Tanja Ernst for her excellent technical assistance. This work was founded by the Deutsche Forschungsgemeinschaft SSP 285 "Molekulare Grundlagen der Evolution bei Pflanzen", He-2671: "Phylogenie und Systematik der carnivoren Familie Nepenthaceae" and SFB 486 "Manipulation von Materie auf der Nanometerskala." H.M. and S.T. contributed equally to this work.

\section{REFERENCES}

1.Schütze, K., I. Becker, K.F. Becker, S. Thalhammer, R. Stark, W.M. Heckl, M. Bohm, and H. Posl. 1997. Cut out or poke in-the key to the world of single genes: laser micromanipulation as a valuable tool on the look-out for the origin of disease. Genet. Anal. 14:1-8.

2.Thalhammer, S., R. Stark, K. Schütze, J. Wienberg, and W.M. Heckl. 1997. Laser microdissection of metaphase chromosomes and characterization by atomic force microscopy. J. Biomed. Optics 2:115-119.

3.Berns, M.W., J. Aist, J. Edwards, K. Strahs, J. Girton, P. McNeill, J.B. Rattner, M. Kitzes, et al. 1981. Laser surgery in cell and developmental biology. Science 213:505-513.

4.Simone, N.L., R.F. Bonner, J.W. Gillespie,

M.R. Emmert-Buck, and L.A. Liotta. 1998. Laser-capture microdissection: opening the microscopic frontier to molecular analysis. Trends Genet. 14:272-276.

5.Schütze, K. and G. Lahr. 1998. Identification of expressed genes by laser-mediated manipulation of single cells. Nat. Biotechnol. 16:737742

6.Thalhammer, S., G. Lahr, A. Clement-Sengewald, W.M. Heckl, R. Burgemeister, and K. Schütze. 2003. Laser microtools in cell biology and molecular medicine. Laser Physics 13:1-11.

7.Hahn, S., X.Y. Zhong, C. Troeger, R. Burgemeister, K. Gloning, and W. Holzgreve. 2000. Current applications of single-cell PCR. Cell Mol. Life Sci. 57:96-105.

8.Schermelleh, L., S. Thalhammer, W. Heckl, H. Posl, T. Cremer, K. Schütze, and M. Cremer. 1999. Laser microdissection and laser pressure catapulting for the generation of chromosome-specific paint probes. BioTechniques 27:362-367.

9.Buzek, J., H. Koutnikova, A. Houben, K. Riha, B. Janousek, J. Siroky, S. Grant, and B. Vyskot. 1997. Isolation and characterization of X-chromosome-derived DNA sequences from a dioecious plant Melandrium album. Chromosome Res. 5:57-65.

10.Hernould, M., K. Glimelius, J. Veuskens, P. Bergman, and A. Mouras. 1997. Microdissection and amplification of coding sequences from a chromosome fragment restoring male fertility in alloplasmic male-sterile tobacco. Plant J. 12:703-709.

11.Wesley, C.S., M. Ben, M. Kreitman, N. Haga, and W.F. Eanes. 1990. Cloning regions of the Drosophila genome by microdissection of polytene chromosome DNA and PCR with nonspecific primer. Nucleic Acids Res. 18:599-603.

12.Engelen, J.J., J.C. Albrechts, G.J. Hamers, and J.P. Geraedts. 1998. A simple and efficient method for microdissection and microFISH. Med. Genet. 35:265-268.

13.Jung, C., U. Claussen, B. Horsthemke, F. Fischer, and R.G. Herrmann. 1992. A DNA library from an individual Beta patellaris chromosome conferring nematode resistance obtained by microdissection of meiotic metaphase chromosomes. Plant Mol. Biol. 20:503-511.

14.Mao, Y.W., S.Y. Liang, W.Q. Song, X.L. Li, and R.Y. Chen. 1998. Construction of a DNA library from chromosome 4 of rice (Oryza sati$v a)$ by microdissection. Cell Res. 8:285-293.

15.Kleeberger, W., T. Rothämel, S. Glöckner, U. Lehmann, and H. Kreipe. 2000. Laser-assisted microdissection and short tandem repeat
PCR for the investigation of graft chimerism after solid organ transplantation. Pathobiology 68:196-201

16.Nagasawa, Y., M. Takenaka, Y. Matsuoka, E. Imai, and M. Hori. 2000. Quantitation of mRNA expression in glomeruli using lasermanipulated microdissection and laser pressure catapulting. Kidney Int. 57:717-723.

17.Greulich, K.O., G. Pilarczyk, A. Hoffmann, G. Meyer zu Horste, B. Schäfer, V. Uhl, and S. Monajembashi. 2000. Micromanipulation by laser microbeam and optical tweezers: from plant cells to single molecules. J. Microsc. 198:182-187.

18.Bayoudh, S., M. Metha, H. RubinszteinDunlop, N.R. Heckenberg, and C. Critchley. 2001. Micromanipolation of chloroplasts using optical tweezers. J. Microsc. 203:214-222.

19.Matsunaga, S., K. Schütze, I.S. Donnison, S.R. Grant, T. Kuroiwa, and S. Kawano. 1999. Technical advance: single pollen typing combined with laser-mediated manipulation. Plant J. 20:371-378.

20.Eichacker, L.A., M. Helfrich, W. Rüdiger, and B. Müller. 1996. Stabilization of chlorophyll a-binding apoproteins P700, CP47, CP43, D2 and D1 by chlorophyll a or Znpheophytin a. J. Biol. Chem. 271:3217432179

21.Schütze, K. and A. Clement-Sengewald. 1994. Catch and move - cut or fuse. Nature 368:667-669.

22.Taberlet, P., L. Gielly, G. Pautou, and J. Bouvet. 1991. Universal primers for amplification of three non-coding regions of chloroplast DNA. Plant Mol. Biol. 17:1105-1109.

23.Dietmaier, W., A. Hartmann, S. Wallinger E. Heinmöller, T. Kerner, E. Endl, K.-W Jauch, F. Hofstädter, et al. 1999. Multiple mutation analyses in single tumor cells with improved whole genome amplification. Am. J. Pathol. 154:83-95.

24.Kuroiwa, T., K. Ishibashi, H. Takano, T. Higashiyama, N. Sasaki, Y. Nishimura, and $\mathrm{S}$. Matsunaga. 1996. Optical isolation of individual mitochondria of Physarum polycephalum for PCR-analysis. Protoplasma 194:275-279.

25.Frey, J.E. 1999. Genetic flexibility of plant chloroplasts. Nature 398:115-116.

26.Bonnet, H.T. and K. Glimelius. 1983. Somatic hybridization in Nicotiana, behavior of organelles after fusion of protoplasts from malefertile and male-sterile cultivars. Theor. Appl. Genet. 65:213-217.

Received 10 December 2002; accepted 27 March 2003.

Address correspondence to:

Dr. Harald Meimberg

Department Biologie I

Bereich Biodiversitätsforschung:

Systematische Botanik

Ludwig-Maximilians-Universität

Menzinger Str. 67

80638 München, Germany

e-mail:meimberg@botanik.biologie.

uni-muenchen.de 